University of Nebraska - Lincoln

DigitalCommons@University of Nebraska - Lincoln

June 1992

\title{
Caste, Class, and Social Change: An Institutionalist Perspective
}

Ann Mari May

University of Nebraska - Lincoln, amay1@UNL.edu

Follow this and additional works at: https://digitalcommons.unl.edu/cbafacpub

Part of the Business Commons

May, Ann Mari, "Caste, Class, and Social Change: An Institutionalist Perspective" (1992). College of Business Faculty Publications. 18.

https://digitalcommons.unl.edu/cbafacpub/18

This Article is brought to you for free and open access by the Business, College of at DigitalCommons@University of Nebraska - Lincoln. It has been accepted for inclusion in College of Business Faculty Publications by an authorized administrator of DigitalCommons@University of Nebraska - Lincoln. 


\section{Caste, Class, and Social Change: An Institutionalist Perspective}

Ann Mari May

When Gunnar Myrdal visited the United States in 1929, he was struck by the extremes of poverty and wealth that existed at the onset of the Great Depression and perplexed by the seeming lack of "class struggle" or "class consciousness" [Jackson 1990, 6365]. Addressing an audience in Geneva, Myrdal later remarked that "patriotic conservatism, capitalist Americanism, spiced with hate and contempt for 'European' subversive dogmas, are not only Main Street's petit bourgeois froth and triumph, but also the slum's compensation for a sad and wretched daily life" [1931, 2056]. In this speech, Myrdal identified the almost "religious nature" with which Americans held the Constitution and Declaration of Independence and viewed this reverence as a "conservative force" that allowed the capitalist system to grow "almost without any restraint" [1931, 205-6].

It was not until a later visit to the United States when he began his research on American race relations that Myrdal more fully developed the notion of "the American creed" and turned it on its head. Whereas Myrdal once viewed the American creed as rationalizing myth, in An American Dilemma he used the American creed "as a dynamic force for equality" [Jackson 1990, 66]. However, Americans' acceptance of the "myth of classlessness" led Myrdal to make his appeals for social justice not through

The author is Assistant Professor of Economics, University of Nebraska, Lincoln. This article was presented at the annual meeting of the Association for Evolutionary Economics, New Orleans, Louisiana, January 2-5, 1992. 
the language of class, but through equality. The conflict that Myrdal chose to illuminate was not class conflict, but the conflict between the reality of economic life for many Americans and our vision of what we believed about ourselves.

Although institutionalists like Gunnar Myrdal, as well as others such as Thorstein Veblen, Clarence Ayres, and John Kenneth Galbraith, have invoked "class and caste" distinctions, institutionalists have often eschewed the notion of class, perhaps because of its Marxian connotation or perhaps because it was analytically difficult to use. As Myrdal's study of race relations shows, class analysis is often difficult to apply when analyzing the United States. But is the concept of class a useful concept for institutionalists, and is there a difference between the Marxian notion of class and the use of class and caste by institutionalists? In this paper, we will examine these questions and attempt to determine what role caste and class distinctions play in promoting progressive social change.

Within Marxism, the notion of class has largely been interpreted in the narrowly economic sense in which class distinctions result from a group's relation to the means of production. Within this simple framework, which focuses on economic relations, class struggle is the inevitable outcome of the relationship between owners of capital and workers.

A similar distinction is reflected in Veblen's dichotomy of workmanship versus ownership, or the common man versus the vested interests [Stanfield 1989]. Yet, Veblen provides the foundation for a broader interpretation of class that extends beyond the economic sphere. For Veblen, class is a cultural outgrowth of a particular system of production, and vested interests are a reflection of pecuniary culture. According to Veblen, the "materialistic" nature of Marxism provides that the "exigencies of the material means of life control the conduct of men in society thruout [sic] ... and shape every shifting trait of human culture ... [whereas] under the Darwinian norm, of cumulative causation, it happens, first; that this initial principle itself is reduced to the rank of a habit of thought ..." [1906, 305].

Not only did Veblen reject the narrow interpretation of class, he also rejected the Marxian inevitability of class struggle. As Veblen saw it, the Marxian view is that divergent class interests will produce class struggle until "the previously less fortunate class gains the ascendancy ..." [1906, 307-8]. However, according to 
Veblen, there is no historical evidence to indicate that societies were moving toward "socialist consummation, in which all divergence of economic interest has lapsed or would lapse" [1906, 308]. This view of class struggle was seen as teleological by Veblen. Moreover, while the logic of Marxian class struggle presupposes that workers will recognize their class interests, Veblen often argued that the "sentiment which animates men, either singly or collectively, is as much, or more, an outcome of habit and native propensity as of calculated material interest" [1906, 308]. Veblen emphasized the power of socialization and the role of emulation in pecuniary culture, as well as the ability of these societies to convince even the most exploited as to the appropriateness of the "established system of subjection and unequal distribution of wealth" $[1906,308]$.

Veblen's early criticisms of Marxism anticipated later criticisms of the more narrow Marxian interpretation of the role of class and the nature of class struggle. While the consensus sociology of the 1950s minimized and often explicitly rejected the notion of class as an organizing concept, class analysis regained popularity in the 1960s. The New Left class analysis was especially concerned, however, with explaining the "new middle class" [for example, see Poulantzas 1975]. According to much of this research, Marxian notions of class were too limited in the sense that they did not provide an adequate framework for examining class relations in a postindustrial service-professional economy.

The New Left class analysis, devoted to defining the contours of class in contemporary society, has reached an impasse, according to Peter Meiksins [1987, 38]. While defining categories and attempting to develop a taxonomy of classes, this research has failed to develop a consensus concerning the boundaries or nature of the "new middle class" or to explain its political significance. More importantly, perhaps, the New Left class analysis has been further debilitated by its failure to provide an adequate rendering of the relationship between gender, race, and class.

As Ann Jennings and William Waller point out, the Marxian focus on economic relations and the narrow interpretation of "economic relations" meant that women's economic roles, if performed in a nonmarket environment, were excluded from analysis. According to Jennings and Waller, "[S]ince women belonged in the home, their disadvantages were not seen as historically significant in economically-based Marxist theories (as they had also 
not been significant in earlier, politically based theories, given women's private roles in the household) except when their presence in the labor market contributed to the depression of wages generally" [unpublished paper, 13]. Marxian analysis of class, according to Jennings and Waller, reflected the double dualism of the nineteenth century-a split between the economy and the state and the economy and the family, in which the economy is predominant.

Moreover, while early views such as those of Oliver Cox link racism to capitalism, they reflect a class reductionist framework. More recent studies of race and class have argued that "racial oppression is not reducible to class exploitation" [Geschwender 1987, 140]. Studies such as Gordon, Reich, and Edwards' Segmented Labor Market Theory [1982] represent a reasonable attempt to integrate class, gender, and race relations in a dual economy characterized by the domination of monopoly capital. Yet, even these studies fail to explain why women and various minorities have come to occupy their positions in the dual economy.

The current impasse in radical political economy over the concept of class opens the way for a reformulation of the concept that is inclusive of race and gender and is, at the same time, both cultural and historical. Thorstein Veblen provides a good framework upon which to build such a reformulation. Veblen's conceptualization of class, as previously noted, rejects the narrow Marxian analysis with its focus on "economic" determinants of class. His analysis has more in common with the notion of social stratification based upon invidious distinctions either on the basis of gender, race, ethnicity, or on our relation to the means of production. Moreover, Veblen's framework encompasses both the stagnant, institutionally structured immobility of caste and the exploitation inherent in the concept of class.

This broader framework is expanded in the work of Jennings, who suggests that class is not determined merely by the relation of a group to the means of production, but that class defines the terms of access to the dominant institutions [Jennings, forthcoming, 35]. In the nineteenth century, Jennings and Waller point out, the dominant institution was economic, or the market. Prior to the nineteenth century, the dominant institution may have been political. In this framework, "Social inequality was understood as the consequence of political inequality" [Jennings and Waller, unpublished paper, 5]. 
This view of class is similar to that of Gunnar Myrdal, who also embraced a culturally specific or determined notion of class. According to Myrdal, "The 'meaning' of social status and of distinctions in social status is not an a priori evident matter. It varies from one culture to another depending upon what is commonly considered important" [1944, 672]. Social status is related to wealth, income, and education, not to mention gender and class, and these factors have different relative importance in determining class structure in different cultures. Moreover, for Myrdal, the concepts of caste and class reflect a continuum of sorts in which "[C]aste may thus in a sense be viewed as the extreme case of absolute rigid class" [1944, 675]. Whereas class lines are "blurred and flexible," caste lines are rigid and inflexible and often defined by custom and law [1944, 675].

Like Veblen, Myrdal's notion of class does not depend upon recognition of common interests. For Myrdal, class consciousness "may or may not be present in this system of interrelated factors determining class position" [1944, 674]. Myrdal rejected the importance of personal identification in the determination of class because of the failure of Americans to recognize their own class status. Myrdal rejected not only the inevitability, but also the relevance of class struggle for the United States as well. More relevant, he argued in his discussions of race relations, is the concept of "caste struggle" because while class consciousness is often lacking in the United States, restrictions imposed by caste relations are often more obvious. Members of caste systems are often aware of their relative positions and immobility in the social structure, as are others in society.

An institutionalist conception of class is culturally dependent and determined by access to the dominant institutions within a particular culture. It follows that class relations must center around the issue of power, rather than exploitation. Within a simple framework, exploitation results from groups occupying certain locations in production, and the focus on exploitation elevates inequality in economic relations over other forms of inequality. In contrast, the concept of power, which as Weber has argued [1954, 323], represents the "possibility of imposing one's will upon the behavior of other persons," is more inclusive, reflecting not only economic power, but political, familial, and other forms of power as well. 
If it is true, as John Kenneth Galbraith has argued [1978, 9], that "people seek to gain greater control over their own lives," then it is incumbent upon us as social scientists to examine the ways in which these dominant institutions exert power, influence, and ultimately control. In the twentieth century, the modern corporation is a focus of power and the dominant economic institution of our time. Institutionalists have contributed much to our understanding of the ways in which the modern corporation bends and shapes the social environment and agenda [Dugger 1989]. However, we have yet to develop an adequate understanding of the ways in which class, gender, and race relations are determined in a dual economy characterized by the domination of monopoly capital.

It is also incumbent upon us as social engineers to examine ways in which people may regain control over their lives and livelihoods. While Veblen may have been cynical about the prospects for social change, subsequent institutionalists such as $\mathbf{M y r}$ dal have often actively sought and promoted progressive social change.

In An American Dilemma, Myrdal utilized class and caste analysis to examine race relations in the United States, but increasingly drew upon the notion of caste, primarily for strategic reasons. Myrdal recognized early in his visits to the United States that American workers were "deeply bourgeois in every sense of the word" [Jackson 1990, 66]. However, while solidarity and identification of common class interests were not characteristics of workers in the United States, recognition of the inherent injustice of caste systems was identifiable and in conflict with our notions of justice and fairness.

These notions of justice and fairness, what Myrdal called "the American Creed," were founded on a shared belief in "civil rights, civil liberties, a free press, and democratic decision making" [Jackson 1990,152] and provided the basis for social change in the area of race relations. While not rejecting the importance of class struggle, agitation, and revolution from the bottom up, Myrdal helped engineer another form of social change that used education as a medium and focused on the middle class. Myrdal sought to expose the inconsistencies of the reality of race relations and its many social and economic consequences with the American creed of equal opportunity. 
Myrdal's approach has a great deal to tell us about social change and American culture. Myrdal, the institutionalist, recognized long ago that class struggle, in the traditional sense, would not provide a basis for a democratic movement in the United States. Instead, he advocated a strategy of highlighting the inconsistencies of "caste and class" in American culture with the American creed of liberal democratic decisionmaking. He recognized that as social engineers, we cannot influence public opinion without recourse to the language and values already existing in that society. In the end, Myrdal exposed the "myth of classlessness" and the falsity of this notion of a harmony of interests, not by stressing the inevitability of class conflict, but by exposing the inconsistency of actual social and economic relations with our belief in equal opportunity.

\section{References}

Dugger, William M. Corporate Hegemony. New York: Greenwood Press, 1989.

Galbraith, John Kenneth. "On Post Keynesian Economics." Journal of Post Keynesian Economics 1 (Fall 1978): 8-11.

Geschwender, James A. "Race, Ethnicity, and Class." In Recapturing Marxism: An Appraisal of Recent Trends in Sociological Theory, edited by Rhonda F. Levine and Jerry Lembcke. New York: Praeger Publishers, 1987.

Gordon, David M., Richard Edwards, and Michael Reich. Segmented Work, Divided Workers: The Historical Transformation of Labor in the United States. Cambridge: Cambridge University Press, 1982.

Jackson, Walter A. Gunnar Myrdal and America's Conscience:

Social Engineering and Racial Liberalism, 1938-1987. Chapel Hill, N.C.: University of North Carolina Press, 1990.

Jennings, Ann L. "Public or Private Institutional Economics and

Feminism." In Beyond "Economic Man": Feminist Theory and Economics, edited by Marianne A. Ferber and Julie A. Nelson. Forthcoming.

Jennings, Ann L., and William T. Waller. "Rethinking Class and Social Stratification: Towards a Coherent Feminist Economics." Unpublished paper.

Meiksins, Peter. "New Classes and Old Theories: The Impasse of Contemporary Class Analysis." In Recapturing Marxism: An 
Appraisal of Recent Trends in Sociological Theory, edited by Rhonda F. Levine and Jerry Lembcke. New York: Praeger Publishers, 1987.

Myrdal, Gunner. "Socialism eller kapitalism i framtidens Amerika?" Tiden 23 (1931). An American Dilemma: The Negro Problem and Modern Democracy. New York: Harper and Brothers Publishers, 1944.

Poulantzas, Nicos. Classes in Contemporary Capitalism. London: New Left Books, 1975.

Stanfield, J. R. "Recent U.S. Marxist Economics in Veblenian Perspective.". In Radical Institutionalism: Contemporary Voices, edited by William M. Dugger. New York: Greenwood Press, 1989.

Veblen, Thorstein. "The Socialist Economics of Karl Marx and His Followers." The Quarterly Journal of Economics 20 (1906): 299-322.

Weber, Max. Max Weber on Law in Economy and Society. Cambridge: Harvard University Press, 1954. 